\title{
A MULTIPLE CRITERIA DECISION-MAKING APPROACH TO THE SELECTION OF CONCRETE PUMPS
}

\author{
Serdar Ulubeyli ${ }^{1}$, Aynur Kazaz ${ }^{2}$ \\ Civil Engineering Department, Engineering Faculty, Akdeniz University, 07058 Antalya, Turkey \\ E-mails: ${ }^{1}$ serulubey@yahoo.com; ${ }^{2}$ akazaz@akdeniz.edu.tr \\ Received 15 Feb 2009; accepted 18 Sept 2009
}

\begin{abstract}
In this study, the ELECTRE III method, which is one of the most common techniques among multiple criteria decision-making (MCDM) approaches, was considered in a selection problem of concrete pumps. As a methodological framework, a two-step questionnaire survey was conducted by 70 firms that have and use concrete pumps. A solution of the problem was then found in the light of the real world data by means of ELECTRE III. The paper can be of value to researchers studying the anatomy of decision-making in equipment selection in general and investigating selection criteria of concrete pumps in particular. It also contributes to the academic environment as an application practice of ELECTRE III to correspond with the nature of equipment selection and as an effective means for the formalization of knowledge possessed by industrial practitioners. On the practical side, ELECTRE III offers an efficient and convenient tool that forces the users into orderly and methodical thinking, and guides them in making logical and robust decisions. In addition, the example illustrated in the present study can be helpful for decision-makers dealing with similar equipment selection issues.
\end{abstract}

Keywords: concrete pump, construction equipment, ELECTRE III, multiple criteria decision-making, selection.

\section{Introduction}

Decision-making or "problem solving", as a broader term, is the process of selecting one or a few alternatives that should be the most favourable one(s) to objective(s). In this respect, the choice of construction equipment can be handled as a multiple-criteria decision-making problem. In order to reach an optimum decision, well-defined criteria and superb solution techniques are required. Selection should also be based on extreme conditions rather than average conditions. However, each decision problem has it's own particular conditions and factors, and decision-makers are different from each other. Even the same decision-maker may have completely opposite decisions for the same problem in different times. In addition, there are always some intangible areas to be considered while comparing different alternatives. These are difficult to quantify, but exhibit considerable influences on the final decision, such as experience and personal relationships, which can be assumed as qualitative information. In this context, the ELECTRE III technique allows that quantitative data are evaluated together with qualitative data. It can analyze different-type criteria without converting them into a single scale. This method has a dynamic character as well, because it can prevent many drawbacks appeared by committing specific numerical values as in most of this kind of methods such as Analytic Hierarchy Process (AHP). It also gives a ranking order of alternatives, rather than presenting only one option. This provides ELECTRE III a flexible feature which, in turn, makes decision-makers feel more comfortable and independent. Moreover, Zavadskas et al. (2004) have found out that ELECTRE III, as a comparative preference method, is completely suitable for solving the selection task of commercial object investment. Therefore, it is evident that ELECTRE III is one of the most suitable methods, supporting the machine selection process. As a limitation of the method, however, note importantly that it can be utilized when at least 3 and at most 13 decision criteria are available (Figueira et al. 2005).

There exist 2 main reasons of why concrete pump was chosen as a construction machine in this study: (i) it is inevitable to employ concrete pumps in construction projects including concrete-based products; (ii) it is a highly risky decision whether to purchase concrete pumps, requiring a great financial investment that can be measured with a million dollars. In addition to these arguments, the use of suitable concrete pump on the job site may improve site productivity, may increase the quality of products and services, and may reduce the duration and the cost of the task 'pouring concrete'. In the long run, this can contribute to the related firms in improving their competitiveness and in outperforming their competitors in the construction industry. As a result, it is aimed in this study that concrete pumps of which selection process has been investigated only one time to date are examined using ELECTRE III. However, suggesting a rigid conceptual model for the selection factors of concrete pumps cannot contribute to the concluding solution. Instead, criteria that are paid attention by pump users working in 
Turkey, a region of temperate climate, were introduced in the present study. New ones, of course, may be added in special cases when required. For instance, an optional criterion related to the heating mechanism in concrete pumps can be attached to the approach offered in this paper, if potential customers will do business in extremely cold regions of the world.

\section{Past studies}

There are numerous works regarding the choice of construction equipment. These are given in Table 1 chronologically. As can be seen in these past researches, ELECTRE III is an ignored solution tool except the study of Tam et al. (2003) in the selection process of construction machines. On the other hand, Tam et al. (2003) investigated concrete vibrators which have very different features and criteria when compared. In addition, this study included 5 criteria, all of them of a quantitative nature. Although Tam et al. (2004) examined concrete pumps, their method is different from ELECTRE III and they solely consider quantitative criteria. Moreover, 10 concrete pumps, which characteristics vary in a very large spectrum, were investigated. In reality, this is incongruous with the basic MCDM logic because of the fact that MCDM is a useful and reasonable device employed when there are little differences between the characteristics of alternatives and thereby when the selection process is a tough and indecisive work.

\section{ELECTRE III}

The word ELECTRE is the abbreviation of "Elimination et Choix Traduisant la Realite - Elimination and choice expressing the reality". This method was developed by Benayoun and his colleagues; but later, Roy, Nijkamp, and van Delft considerably improved the method until reaching its present state (Roy 1996). ELECTRE III is the most frequently used method in the ELECTRE family; it is composed of 7 versions (Roy 1978) such as ELECTRE-IV (Ustinovichius et al. 2006). The basic idea of this approach is the ranking of alternatives according to the prioritization level. It is based on pair-wise comparisons indicating the degree of dominance of one alternative or group of alternatives over the remaining ones for each decision criterion (Nijkamp et al. 1990). ELECTRE III was designed to improve ELECTRE II, and thus to deal with inaccurate, imprecise, uncertain or ill-determination of data, i.e. qualitative data. New ideas introduced by this method are the use of pseudo-criteria revealing the threshold concept, and fuzzy binary outranking relationships. ELECTRE III not only evaluates the best choice, and this should not be perceived as a structural deficiency of the method. On the contrary, it presents a specific ranking and leaves the last selection judgment to the decision maker(s). The procedure of using ELECTRE III is best illustrated in the following steps.

Veto $(v)$, indifference $(q)$, and preference $(p)$ thresholds must be defined as the expression $v_{j}\left(g_{j}(*)\right) \geq p_{j}\left(g_{j}(*)\right) \geq q_{j}\left(g_{j}(*)\right)$ by the decision maker(s) for all criteria provided that the level of performance of one of the options is shown by $g_{j}(*)$ for the jth criterion. Threshold values in ELECTRE family methods can be accepted as a kind of tolerance. Concordance index, $C(a, b)$, is computed for each pair $(a, b)$ of options, in which option $a$ is at least equally high in the priority or$\mathrm{der}$, as option $\mathrm{b}$ is signified. Here, $c_{j}(a, b)$ symbolizes the individual comparison index, and $w_{j}$ - the importance weight of each criterion. The concordance matrix $C$, which is not symmetric in general, is composed of these concordance indices. Furthermore, successive equations $c_{1,1}=c_{2,2}=\ldots=c_{m, m}=1$ are valid in the matrix, where

Table 1. Previous papers concerning the selection problem of construction machines

\begin{tabular}{lll}
\hline \multicolumn{1}{c}{ Author } & \multicolumn{1}{c}{ Type of equipment } & \multicolumn{1}{c}{ Selection method } \\
\hline Chan and Harris (1989) & Backhoe/loader & Electronic spreadsheet \\
Jayawardane and Harris (1990) & Earthwork equipment & Linear programming \\
Amirkhanian and Baker (1992) & Earth-moving equipment & Expert system \\
Hanna (1994) & Crane & Expert system \\
Touran et al. (1997) & Dozer & Empirical charts \\
Hanna and Lotfallah (1999) & Crane & Fuzzy logic \\
Naoum and Haidar (2000) & Opencast mine equipment & Genetic algorithms \\
Sawhney and Mund (2002) & Crane & Neural networks \\
Tam et al. (2003) & Concrete vibrator & ELECTRE III \\
Tam et al. (2004) & Concrete pump & Superiority and inferiority ranking \\
Al-Hussein et al. (2005) & Mobile crane & Optimization algorithm \\
Goldenberg and Shapira (2007) & Concreting equipment & Analytical hierarchy process \\
Schabowicz and Hola (2007, 2008) & Earth-moving machinery & Mathematical-neural networks \\
Sivilevičius et al. (2008) & Asphalt mixing plant & Simple additive weighting \\
Zavadskas and Vaidogas (2008) & Protective equipment & Bayesian approach \\
\hline
\end{tabular}


$m$ shows the number of alternatives. Although the matrix $W$ of total weights is calculated (Triantaphyllou et al. 1998), the total of importance weights cannot only become equal to 1 , but also be evaluated in a scale of 10 , 100 or 1000 . For the $j^{t h}$ criterion, the expression "alternative $a$ is absolutely better than alternative $b$ " or the statement "alternative $b$ is absolutely preferable to alternative $a$ " can be valid. Otherwise, the fuzzy logic approach must be used, when the outranking relationship between alternatives $a$ and $b$ can not be certainly derived for the $j^{\text {th }}$ criterion. As in concordance index, discordance indices constituting the discordance matrix $D$, also have a value from 0 to 1 . For the $j^{\text {th }}$ criterion, the discordance of the assumption "option $a$ is definitely better than option $b$ " or the supposition "option $b$ is absolutely preferable to option $a$ " can be valid. The veto threshold appeared in case of discordance rejects the hypothesis "option $a$ is better than option $b$ ". The fuzzy logic approach must be again employed, if the outranking relation between options $a$ and $b$ cannot be definitely derived for the $j^{t h}$ criterion. After measuring the concordance and discordance matrices, as the last step, the degree or index of credibility of outranking, which is shown by $S$, is calculated, where the veto threshold is not used or there does not exist any discordance at the judgment "alternative $a$ is at least equally high in the priority order as alternative $b$ " for all criteria. Contrary to this outcome, in case of $D_{j}(a, b)>C_{j}(a, b)$, the inequality $S<C$ becomes valid for the concordance matrix which value decreases with the presence of discordance matrix. Even $S=0$ is found out in case of $D=1$. These credibility scores obtained for each pair of options are then input into the subsequent qualification/distillation process for deriving an overall ranking of all options. For this purpose, $\lambda_{0}$ that equals the maximum value of $S(a, b)$ is first determined. Afterwards, the discrimination threshold $s\left(\lambda_{0}\right)$, which is the composition of preference and indifference thresholds, is found. In this point, Vallee and Zielniewicz (1994) recommended the equation $s(\lambda)=0.3 \lambda-0.15$. As a conclusion, the cut-off level that is analogous to $\lambda$ cut in fuzzy sets is calculated. Consequently, whether the inference "option $a$ is better than option $b$ " $(a S b)$ is covered and controlled.

In every situation where $a$ outranks $b, a$ is given the score +1 (strength) and $b$ is given -1 (weakness). For each option, its individual strengths and weaknesses are added together to give a final qualification score. After this step, distillation procedure is divided into different parts as descending and ascending chains to give two partial preference orderings of the alternatives. Within the downward distillation procedure, the option(s) with the highest qualification score is assigned to the first rank and removed from the procedure, and the process is repeated with all remaining options. When assignment is achieved for all alternatives, the process is complete. Meanwhile, in case of the score equality, only the alternatives that have the same score are graded again by giving scores comparatively. If any outranking relationship between them cannot be still obtained, then it is accepted that they are of the same rank. The upward distillation procedure, by contrast, commences with the selection of the option(s) with the lowest qualification score to assign it or them to the last rank, and uses their successive elimination to produce a ranking. The results of the two chains are combined to yield a final ranking consistent with both. It means that a type of intersection of these two chains is evaluated. These overall calculation procedures of ELECTRE III are demonstrated as a detailed flow chart in Fig. 1.

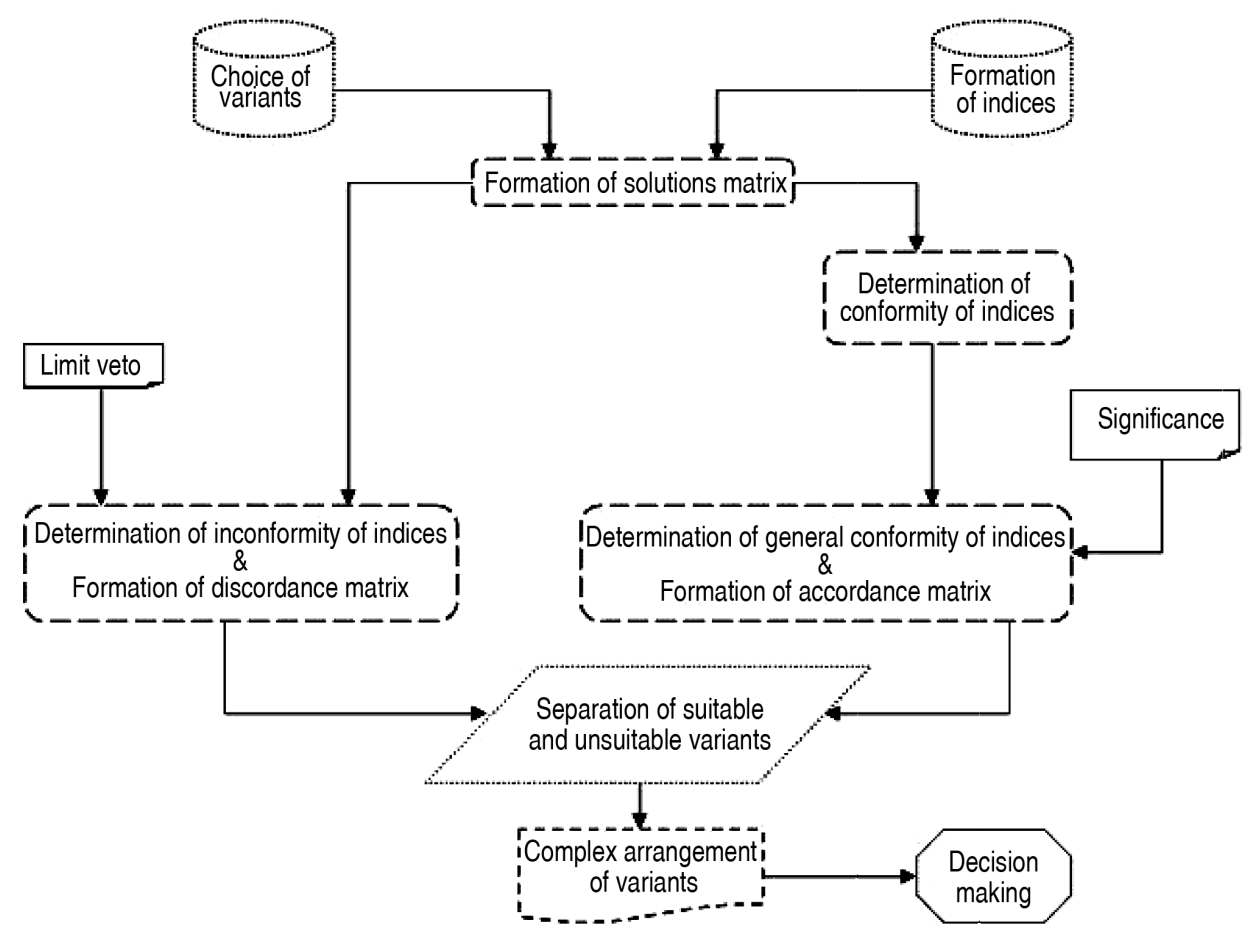

Fig. 1. Flow diagram of the ELECTRE III algorithm (adapted from Zavadskas et al. (2004)) 


\section{Case analysis}

In order to obtain the data needed in the present study, a two-stage questionnaire survey was applied to equipment managers of 70 construction firms using concrete pumps, all of which companies are ready-mixed concrete suppliers in Turkey. To have more accurate answers to the questions directed, the whole interviews were carried out face-to-face from September 2008 to January 2009. In the first phase of the survey, interviewees were asked to express their selection criteria for purchasing concrete pumps by means of an open-ended question. In the second phase, the questionnaire form was divided into 2 parts: (i) questions concerning qualitative criteria of which scores were determined by participants between 0 (none) and 100 (perfect) for each alternative to reveal satisfaction levels of current machine users; (ii) questions concerning the whole criteria of which importance weights were assigned by respondents between 0 (extremely low) and 1 (extremely high), giving the total of 1 appropriate to the ELECTRE III algorithm. In the analysis of the survey, mean values were taken into account both for scores of 2 qualitative criteria and for importance weights of 5 criteria.

In this study, one pump model by 3 different manufacturers, reputable around the world in producing of concrete pumps and the most preferred trademarks in Turkey, was considered. Among them, the concrete pump encoded by $\mathrm{X}-52$ is produced by an Italian company, Y-52 by an American company, and Z-52 by a German company. These 3 models were chosen for this study, since all of them are included on the same pump class (maximum vertical distance of $52 \mathrm{~m}$ ) and thus can be reasonably compared with each other. As it is be seen in Table 2, decision-makers of the concrete pump selection have taken into consideration 3 quantitative and 2 qualitative factors. Data of quantitative criteria were taken from the Turkish distributors of pump manufacturers. Selling prices and average operating costs per day show February-2009 values.

Table 2. Criteria values of alternatives and importance weights of criteria

\begin{tabular}{lcccc}
\hline \multirow{2}{*}{\multicolumn{1}{c}{ Quantitative criteria }} & \multicolumn{3}{c}{ Alternatives } & Weight \\
\cline { 2 - 4 } & $\mathrm{X}-52$ & $\mathrm{Y}-52$ & $\mathrm{Z}-52$ & $\left(w_{j}\right)$ \\
\hline Selling price (1000 US \$) & 760 & 832 & 768 & 0.28 \\
Operating cost per day (US \$) & 416 & 384 & 480 & 0.26 \\
Maximum pumping speed (m $\left.{ }^{3} / \mathrm{h}\right)$ & 179 & 163 & 200 & 0.19 \\
\hline \multicolumn{1}{c}{ Qualitative criteria } & & & & \\
\hline Second hand & 65.7 & 89.1 & 80.3 & 0.11 \\
Technical services & 90.0 & 78.2 & 81.4 & 0.16 \\
\hline
\end{tabular}

A potential pump user can prefer a specific model of a concrete pump due to the following factors:

- A low selling price and operating cost,

- A high pumping speed that decreases the duration of the 'pouring concrete' activity,

- A preferable second hand, indicating both longlasting nature and economical aspect of the machine,
- Inexpensive and fast technical services for maintenance and repair.

The notion behind this five-criteria arrangement of the survey is based on the fact that more robust decisions can be made by taking into acoount qualitative and quantitative attributes together when solving a real-life problem. Moreoever, in the first stage of the questionnaire, participants agreeably stated that they considered these criteria while negotiating on their own selection decisions. However, some factors were not taken into account in this study. Workability or slump, one of them, is a feature of concrete to be poured and does not affect the selection decision. Similarly, maximum suitable aggregate diameter, pipe diameter, and machine power were not considered, because concrete pumps can deliver every sort of concrete. Moreover, these factors are naturally represented under the 'maximum pumping speed' criterion. In addition, weight or speed of the vehicle could be accepted as a different criterion, but all concrete pumps can gain a speed up to the allowed legal limit $(\leq 110 \mathrm{~km} / \mathrm{h})$ in highways. Although maximum vertical distance and maximum horizontal reach are the most important technical characteristics of concrete pumps, all 3 models have same numerical values of $52 \mathrm{~m}$ and $48 \mathrm{~m}$, respectively. If these values of the models were different from each other, they would be naturally included in selection criteria.

Threshold values taken in the calculation stage are in Table 3. Both indifference threshold $(q)$ and preference threshold $(p)$ are explained depending on the performance level of alternative $a$. On the other hand, threshold values of the whole criteria could also be taken as a constant or a complex function such as $\alpha^{*} g(a)+\beta$. In terms of this expression, this paper accepted the constants as $\alpha=0.05$ and $\beta=0$. The range of the difference in performance of the alternatives for each criterion is not large in reality. Thus, the veto threshold is not applicable in this example and so was disabled.

Table 3. Threshold values

\begin{tabular}{lc}
\hline Indifference threshold $-q(g(a))$ & $0.05 * g(a)$ \\
Preference threshold $-p(g(a))$ & $0.05^{*} g(a)$ \\
Veto threshold $-v(g(a))$ & - \\
\hline
\end{tabular}

Since criteria, alternatives, performances, and thresholds are defined exactly in the problem, concordance and credibility matrices (Table 4) were calculated initially. Because of the validity of the case $D_{j}(a, b) \leq C(a, b)$ in this example, both matrices give the same numerical values.

Table 4. Concordance and credibility matrices

\begin{tabular}{|c|c|c|c|}
\hline & $X-52$ & $Y-52$ & Z-52 \\
\hline$X-52$ & 1.00 & 0.63 & 0.70 \\
\hline$Y-52$ & 0.37 & 1.00 & 0.53 \\
\hline Z-52 & 0.58 & 0.63 & 1.00 \\
\hline
\end{tabular}


The next step of the ELECTRE III algorithm, the descending distillation was first carried out. As shown in Fig. 2, X-52 was found to be the top alternative, followed by the equal ranking of Y-52 and Z-52.

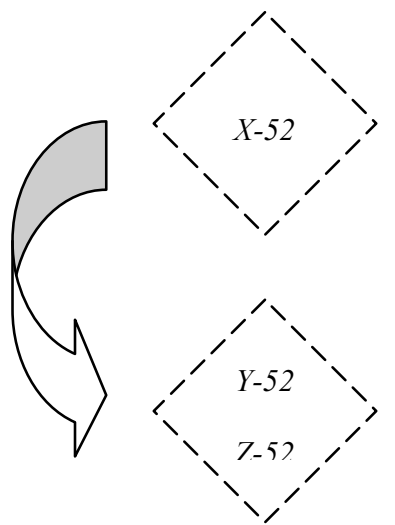

Fig. 2. Result of the descending distillation

The ascending distillation was then evaluated (Fig. 3). According to this chain, X-52 and Z-52 have the same rank, followed by a less preferable alternative, Y-52.

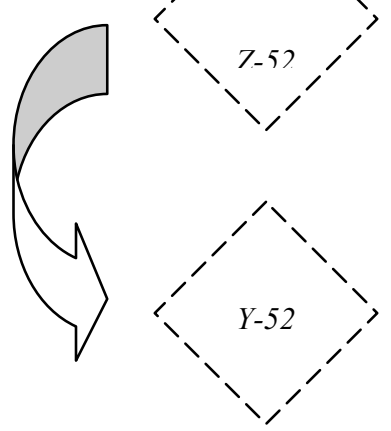

Fig. 3. Result of the ascending distillation

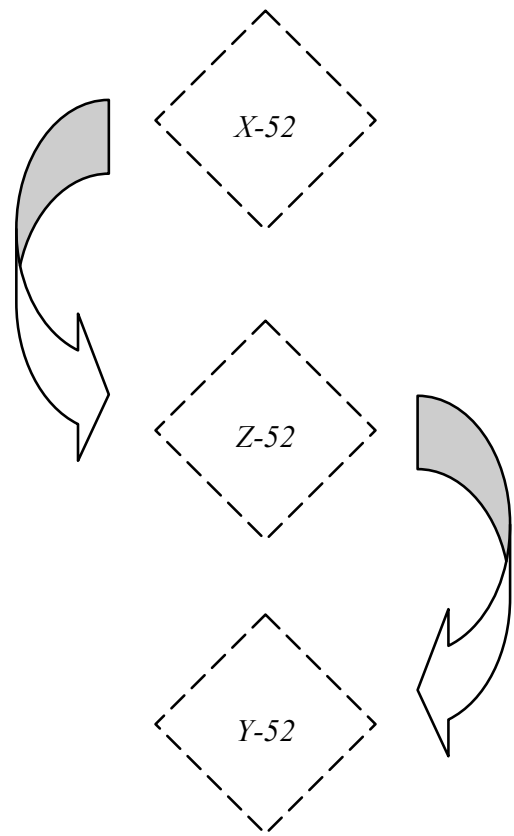

Fig. 4. Final ranking of concrete pumps
Performing a combination procedure, the final ranking was obtained (Fig. 4). Among 3 concrete pumps, $\mathrm{X}-52$ can be approved by decision maker(s) as the best alternative with the intention of purchasing. Z-52 is proposed to customer firms, which may not choose the X-52 model. Finally, Y-52 is the least proper concrete pump.

\section{Sensitivity analysis}

Before making the last decision, whether there would be any difference in the final ranking was tested by reconsidering potential values of chosen parameters $(p, q, v$, $w$ ) in a reasonable manner. A sensitivity analysis showing the influence of these changes on the final result was carried out for this objective. A sensitivity analysis can be performed to check the sensitivity of the final decisions to minor changes in judgments and hypotheses. The decision-maker can check the sensitivity of his judgements on the overall priorities of alternatives by trying various values for his comparison. Especially uncertain data inputs may be slightly changed, and how it affects the final result can be examined. Thus, a more healthy decision can be made. For the case analysis in this study, which criteria and which parameters bore on the final estimation or on the position in the final outranking list were described. To this aim, experimental values were employed, reflecting the lower and upper boundaries of preference threshold $(p)$, indifference threshold $(q)$, and weights of criteria $\left(w_{j}\right)$. It means that each variant $(\alpha, w)$ was individually altered, keeping all the remaining conditions the same. Threshold values were first tested, and the $\alpha$ value of 0.05 used in calculating preference $(p)$ and indifference $(q)$ thresholds was changed. On the other hand, veto threshold $(v)$ was neglected as in the original evaluation. It is evident that X-52 is almost always the best option except for the case ' $\alpha=0.10$ '. When the constant $\alpha$ takes more sensitive or smaller values, Z-52 becomes a better alternative than Y-52. As an interesting finding, it is a vain attempt to give 0.11 or greater values to the constant $\alpha$, since none of the concrete pumps has superiority over others (Table 5).

Besides the constant $\alpha$, weights of five criteria $\left(w_{j}\right)$ are the other parameter type that can likely have a changing effect on the final list. The weight of the 'selling price' criterion is one of them. As can be seen in Table 6, $\mathrm{X}-52$ holds its uppermost position in general. For greater values than $0.23, \mathrm{Z}-52$ seems to be the second alternative. However, if smaller weights than 0.23 are accepted, the decision process is neutralized.

In Table 7, the complex interaction between the final result and the weight of the 'operating cost per day' criterion is shown. As usual, X-52 is the best concrete pump, if the weight does not take 0.54 or greater values. When the fact that the total of five weights must be equal to 1.00 is considered, decision makers probably do not give such a big value to this weight. On the other hand, the smaller values the weight takes, the better option Z-52 becomes when compared with Y-52.

'Maximum pumping speed' is the third criterion of which weight the final selection decision can vary. As shown in Table 8, X-52 protects its superior position on 
Table 5. Variation of the final result with $\alpha$

\begin{tabular}{|c|c|c|c|c|c|c|c|}
\hline \multicolumn{2}{|c|}{$\alpha$} & 0.01 & $0.02-0.04$ & $0.05-0.07$ & $0.08-0.09$ & 0.10 & 0.11 -more \\
\hline \multirow{3}{*}{$\begin{array}{l}\text { Final } \\
\text { result }\end{array}$} & 1. & $X-52$ & $X-52=Z-52$ & $X-52$ & $X-52$ & $\mathrm{Y}-52$ & $\mathrm{X}-52=\mathrm{Y}-52=\mathrm{Z}-52$ \\
\hline & 2. & $\mathrm{Z}-52$ & Y-52 & $Z-52$ & Y-52 & $X-52$ & \\
\hline & 3. & $Y-52$ & & Y-52 & $Z-52$ & $\mathrm{Z}-52$ & \\
\hline
\end{tabular}

Table 6. Variation of the final result with the weight of 'selling price'

\begin{tabular}{|c|c|c|c|c|}
\hline Selling & veight & $w \leq 0.23$ & $0.23<w<0.36$ & $0.36 \leq w$ \\
\hline \multirow{3}{*}{$\begin{array}{l}\text { Final } \\
\text { result }\end{array}$} & 1. & $\mathrm{X}-52=\mathrm{Y}-52=\mathrm{Z}-52$ & $X-52$ & $X-52=Z-52$ \\
\hline & 2. & & $Z-52$ & Y-52 \\
\hline & 3. & & Y-52 & \\
\hline
\end{tabular}

Table 7. Variation of the final result with the weight of 'Operating cost per day'

\begin{tabular}{lccccccc}
\hline \multicolumn{2}{c}{$\begin{array}{c}\text { Operating cost's } \\
\text { weight }\end{array}$} & $w \leq 0.19$ & $0.19<w<0.29$ & $0.29 \leq w<0.32$ & $0.32 \leq w<0.47$ & $0.47 \leq w<0.54$ & $0.54 \leq w$ \\
\hline \multirow{2}{*}{ Final } & 1. & $\mathrm{X}-52=\mathrm{Z}-52$ & $\mathrm{X}-52$ & $\mathrm{X}-52=\mathrm{Y}-52=\mathrm{Z}-52$ & $\mathrm{X}-52$ & $\mathrm{X}-52=\mathrm{Y}-52$ & $\mathrm{Y}-52$ \\
result & 2. & $\mathrm{Y}-52$ & $\mathrm{Z}-52$ & & $\mathrm{Y}-52$ & $\mathrm{Z}-52$ & $\mathrm{X}-52$ \\
& 3. & & $\mathrm{Y}-52$ & & $\mathrm{Z}-52$ & & $\mathrm{Z}-52$ \\
\hline
\end{tabular}

Table 8. Variation of the final result with the weight of 'Maximum pumping speed'

\begin{tabular}{ccccccc}
\hline \multicolumn{2}{c}{$\begin{array}{c}\text { Pumping speed's } \\
\text { weight }\end{array}$} & $w \leq 0.13$ & $w=0.14$ & $0.14<w<0.28$ & $0.28 \leq w<0.42$ & $0.42 \leq w$ \\
\hline \multirow{2}{*}{ Final } & 1. & $\mathrm{X}-52$ & $\mathrm{X}-52=\mathrm{Y}-52=\mathrm{Z}-52$ & $\mathrm{X}-52$ & $\mathrm{X}-52=\mathrm{Z}-52$ & $\mathrm{Z}-52$ \\
result & 2. & $\mathrm{Y}-52$ & & $\mathrm{Z}-52$ & $\mathrm{Y}-52$ & $\mathrm{X}-52$ \\
& 3. & $\mathrm{Z}-52$ & & $\mathrm{Y}-52$ & $\mathrm{Y}-52$ \\
\hline
\end{tabular}

Table 9. Variation of the final result with the weight of 'Second hand'

\begin{tabular}{lcccccc}
\hline \multicolumn{2}{c}{$\begin{array}{c}\text { Second hand's } \\
\text { weight }\end{array}$} & $w \leq 0.05$ & $0.05<w<0.15$ & $0.15 \leq w<0.36$ & $w=0.36$ & $0.37 \leq w$ \\
\hline \multirow{2}{*}{ Final } & 1. & $\mathrm{X}-52$ & $\mathrm{X}-52$ & $\mathrm{X}-52=\mathrm{Y}-52=\mathrm{Z}-52$ & $\mathrm{Y}-52$ & $\mathrm{Y}-52$ \\
result & 2. & $\mathrm{Y}-52=\mathrm{Z}-52$ & $\mathrm{Z}-52$ & & $\mathrm{X}-52$ & $\mathrm{Z}-52$ \\
& 3. & & $\mathrm{Y}-52$ & & $\mathrm{Z}-52$ & $\mathrm{X}-52$ \\
\hline
\end{tabular}

the condition that the weight is smaller than 0.42. As another finding, in greater values of the weight, Z-52 seems to be a more preferable alternative.

In Table 9, how the weight of the 'second hand' criterion turns the final decision into another direction is presented. Up to the value of $0.15, \mathrm{X}-52$ can be chosen as the best concrete pump. In a large interval between 0.15 and 0.36 , all of the three alternatives are tied for the first place in the final list. However, if 0.36 or greater values are given to the weight, then Y-52 occupies the highest rank.

The weight of the 'technical services' criterion is the last variable under consideration in the sensitivity analysis. As can be seen in Table 10, if greater values than 0.11 are assigned for the weight, $\mathrm{X}-52$ is calculated as the best option that may be selected by decision maker(s). However, if 0.11 or smaller weights are accepted, the equality in rank is valid for three alternatives.

Consequently, after making the projected changes in input data, it was observed that the final ranking order of three concrete pumps was not significantly altered except for some particular cases. In other words, X-52 was proved to be the top alternative, followed by Z-52 and Y-52, respectively. In addition to this approving finding, some individual variants was found to have serious impacts on the final result. The most influential criterion is 'second hand' in this respect. When its weight takes 0.36 or greater values, then Y-52 dominantly becomes the best concrete pump and X-52 falls to the least preferable rank. 'Maximum pumping speed' is another one. On the condition that 0.42 or greater values are given to the weight, $\mathrm{Z}-52$ rises to the first place by a little difference instead of $\mathrm{X}-52$. As the last criterion, 'operating cost per day' is also revealed. When 0.54 or greater values are assigned to its weight, Y-52 is replaced by X-52 for the top rank and becomes a slightly better alternative. Besides these three criteria, the constant $\alpha$ absolutely affects the first rank in only one case. Namely, when the constant $\alpha$ is equal to $0.10, \mathrm{Y}-52$ possesses moderate superiority over X-52. On the other hand, none of 'technical services' and 'selling price' has a major influence over the final order, but just producing a tying position in some circumstances, as showed in Tables 6 and 10. 
Table 10. Variation of the final result with the weight of 'Technical services'

\begin{tabular}{|c|c|c|c|c|}
\hline Technica & weight & $w \leq 0.11$ & $0.11<w<0.23$ & $0.23 \leq w$ \\
\hline \multirow{3}{*}{$\begin{array}{l}\text { Final } \\
\text { result }\end{array}$} & 1. & \multirow[t]{3}{*}{$\mathrm{X}-52=\mathrm{Y}-52=\mathrm{Z}-52$} & $X-52$ & $X-52$ \\
\hline & 2. & & $\mathrm{Z}-52$ & \multirow[t]{2}{*}{$Y-52=Z-52$} \\
\hline & 3. & & $Y-52$ & \\
\hline
\end{tabular}

\section{Conclusions}

Since selection factors vary for each construction machine such as concrete pumps, it is impossible to produce a general solution for this kind of selection problems. Instead, specific criteria should be established for each machine type, and more importantly, they should not only be based on theoretical background or literature review but also reflect practitioners' points of view, as realized in this present study. There is also no doubt that a sound or the best MCDM technique can not be found, because all of the solution methods are based on some restrictive assumptions. However, it is inevitable for decision makers to be aware of constraints and drawbacks of the methods employed, and then to evaluate the results accordingly. In this respect, ELECTRE III provides a reliable medium that can also be adapted to other selection problems in the management domain of civil engineering as well as in other disciplines.

Companies that plan to purchase new concrete pumps should first determine machine models by considering maximum vertical and horizontal distances according to their requirements. After that, the data of three quantitative criteria presented in this study should be taken from various manufacturers, and the data of the remaining two qualitative criteria should be obtained by means of an indepth market research. If there are some additional criteria in that geographical location, they should also be taken into account. Importance weights of selection factors should then be negotiated by decision maker(s). Hence, the final decision can be made by properly following ELECTRE III procedures explained in this paper.

In terms of the initial final result obtained from the case analysis, X-52 was found out to be the most suitable concrete pump, followed by Z-52 and Y-52, respectively. Considering six independent experimental attempts of sensitivity analysis (Table 5-10), the overall findings point out that the original outcome was not considerably changed. However, the 'second hand' criterion was denoted as strongly influencing the final ranking order. 'Maximum pumping speed', 'operating cost per day', and the constant $\alpha$ are other parameters that can potentially and slightly change the selection decision. Although 'technical services' and 'selling price' are important inputs in the evaluation process, they do not severely bear on the final outranking order.

\section{Acknowledgements}

The authors gratefully acknowledge the numerous equipment managers of the surveyed companies for their generous collaboration, contributions, and assistance. The authors also would like to thank the financial support provided by the Committee on Research Grants of Akdeniz University.

\section{References}

Al-Hussein, M.; Alkass, S.; Moselhi, O. 2005. Optimization algorithm for selection and on site location of mobile cranes, Journal of Construction Engineering and Management 131(5): 579-590. doi:10.1061/(ASCE)0733-9364(2005)131:5(579)

Amirkhanian, S.; Baker, N. 1992. Expert system for equipment selection for earth-moving operations, Journal of Construction Engineering and Management 118(2): 318-331. doi:10.1061/(ASCE)0733-9364(1992)118:2(318)

Chan, C. M. R.; Harris, F. C. 1989. A database/spreadsheet application for equipment selection, Construction Management and Economics 7: 235-247.

Figueira, J.; Mousseau, V.; Roy, B. 2005. ELECTRE Methods, in Figueira, J.; Greco, S.; Ehrgott, M. (Ed.). Multiple Criteria Decision Analysis: State of the Art Surveys. Boston: Springer Verlag, 133-162.

Goldenberg, M.; Shapira, A. 2007. Systematic evaluation of construction equipment alternatives: case study, Journal of Construction Engineering and Management 133(1): 7285. doi:10.1061/(ASCE)0733-9364(2007)133:1(72)

Hanna, A. S. 1994. Selectcrane: an expert system for optimum crane selection, in Proceedings of the $1^{\text {st }}$ congress, Computing in Civil Engineering. Washington, USA, 958-963.

Hanna, A. S.; Lotfallah, W. B. 1999. A fuzzy logic approach to the selection of cranes, Automation in Construction 8: 597-608. doi:10.1016/S0926-5805(99)00009-6

Jayawardane, A. K. W.; Harris, F. C. 1990. Further development of integer programming in earthwork optimization, Journal of Construction Engineering and Management 116: 18-34. doi:10.1061/(ASCE)0733-9364(1990)116:1(18)

Naoum, S.; Haidar, A. 2000. A hybrid knowledge based system and genetic algorithms for equipment selection, Engineering, Construction, and Architectural Management 7(1): 314. doi:10.1046/j.1365-232x.2000.00128.x

Nijkamp, P.; Rietveld, P.; Voogd, H. 1990. Multicriteria Evaluation in Physical Planning. Amsterdam: NorthHolland.

Roy, B. 1978. ELECTRE III: un algorithme de classement fonde sur une representation floue des preferences en presence de criteres multiples (ELECTRE III: the algorithm of classification based on dim representation of preferences at presence multi-criteria), Cahiers $d u$ CERO 20(1): 3-24 (in French).

Roy, B. 1996. Multicriteria Methodology for Decision Aiding. Dortrecht: Kluwer Academic Publishers.

Sawhney, A.; Mund, A. 2002. Adaptive probabilistic neural network-based crane type selection system, Journal of Construction Engineering and Management 128(3): 265273. doi:10.1061/(ASCE)0733-9364(2002)128:3(265) 
Schabowicz, K.; Hola, B. 2007. Mathematical-neural model for assessing productivity of earthmoving machinery, Journal of Civil Engineering and Management 13(1): 47-54.

Schabowicz, K.; Hola, B. 2008. Application of artificial neural network in producting earthmoving machinery effectiveness ratios. Archives of Civil and Mechanical Engineering 8(4): 73-84.

Sivilevičius, H.; Zavadskas, E. K.; Turskis, Z. 2008. Quality attributes and complex assessment methodology of the asphalt mixing plant, The Baltic Journal of Road and Bridge Engineering 3(3): 161-166. doi:10.3846/1822-427X.2008.3.161-166

Tam, C. M.; Tong, T. K. L.; Lau, C. T. 2003. ELECTRE III in evaluating performance of construction plants: case study on concrete vibrators, Construction Innovation 3: 45-61.

Tam, C. M.; Tong, T. K. L.; Wong, Y. W. 2004. Selection of concrete pump using the superiority and inferiority ranking method, Journal of Construction Engineering and Management 130(6): 827-834. doi:10.1061/(ASCE)0733-9364(2004)130:6(827)

Touran, A.; Sheahan, T. C.; Ozcan, E. 1997. Rational equipment selection method based on soil conditions, Journal of Construction Engineering and Management 123(1): 8588. doi:10.1061/(ASCE)0733-9364(1997)123:1(85)
Triantaphyllou, E.; Shu, B.; Sanchez, S. N.; Ray, T. 1998. Multi-criteria decision making: an operations research approach, in Webster, J. G. (Ed.). Encyclopedia of Electrical and Electronics Engineering. New York: John Wiley \& Sons, 15: 175-186.

Ustinovichius, L.; Zavadskas, E. K.; Lunkevichius, S.; Shevchenko, G. 2006. Multiple criteria analysis for assessing the investment projects in rural property revitalization, in International Conference on Operational Research: Simulation and Optimisation in Business and Industry, May 17-20, Tallinn, Estonia, 194-199.

Vallee, D.; Zielniewicz, P. 1994. ELECTRE III-IV, Version 3.x: Guide d'Utilisation, Document de LAMSADE, No. 85, Universite de Paris-Dauphine, France.

Zavadskas, E. K.; Ustinovichius, L.; Stasiulionis, A. 2004. Multicriteria valuation of commercial construction projects for investment purposes, Journal of Civil Engineering and Management 10(2): 151-166.

Zavadskas, E. K.; Vaidogas, E. R. 2008. Bayesian reasoning in managerial decisions on the choice of equipment for prevention of industrial accidents, Inzinerine Ekonomika Engineering Economics 5(60): 32-40.

\section{DAUGIATIKSLIO SPRENDIMO PRIĖMIMO METODO TAIKYMAS PARENKANT BETONO SIURBLIUS}

\section{S. Ulubeyli, A. Kazaz}

S a n tra k a

Šio tyrimo ELECTRE III metodas - vienas dažniausiai taikomų metodų iš daugiatikslių sprendimo priemimo metodų buvo pritaikytas betono siurblių parinkimo uždaviniui spręsti. 70 įmonių buvo apklaustos dviem etapais. Tuomet buvo išspręstas realus uždavinys realiais duomenimis, taikant ELECTRE III metodą. Straipsnis gali būti naudingas tyrejjams, nagrinėjantiems ỉrenginių parinkimo uždavinių prigimti ir esmę. Šis straipsnis turi akademinę ir praktinę vertę, nes išreiškia efektyvių sprendimų prièmimo proceso esmę ir pateikia tvirtą sprendimo prièmimo pagrindą. Pateiktas praktinio uždavinio sprendimas yra gera metodinè priemonè parenkant statybinius mechanizmus.

Reikšminiai žodžiai: betono siurblys, statybinis įrengimas, ELECTRE III, daugiatikslis sprendimų priemmimas, parinkimas.

Serdar ULUBEYLI. Doctor of Construction Management Division in Civil Engineering Department at Akdeniz University, Turkey. His areas of academic research interests include subcontracting, international construction, labour productivity, total quality management, and project management. He has published many papers in various journals and proceedings.

Aynur KAZAZ. Associate Professor of Construction Management Division in Civil Engineering Department at Akdeniz University, Turkey. Her areas of academic expertise include construction management, total quality management, labour productivity, project management, and construction economy. Author of many papers published in professional journals and conference proceedings. 